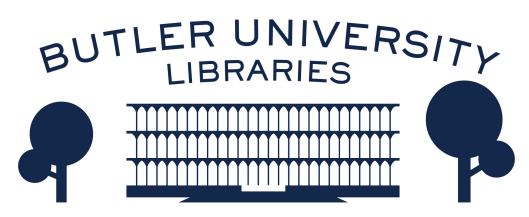

Journal of Hindu-Christian Studies

Volume 27

Article 8

November 2014

\title{
Hindu Responses to Religious Diversity and the Nature of Post- Mortem Progress
}

Ankur Barua

University of Cambridge

Follow this and additional works at: https://digitalcommons.butler.edu/jhcs

Part of the History of Religions of Eastern Origins Commons

\section{Recommended Citation}

Barua, Ankur (2014) "Hindu Responses to Religious Diversity and the Nature of Post-Mortem Progress," Journal of Hindu-Christian Studies: Vol. 27, Article 8.

Available at: https://doi.org/10.7825/2164-6279.1580

The Journal of Hindu-Christian Studies is a publication of the Society for Hindu-Christian Studies. The digital version is made available by Digital Commons @ Butler University. For questions about the Journal or the Society, please contact cbauman@butler.edu. For more information about Digital Commons @ Butler University, please contact digitalscholarship@butler.edu. 


\title{
Hindu Responses to Religious Diversity and the Nature of Post-Mortem Progress
}

\author{
Ankur Barua \\ University of Cambridge
}

THE last two hundred years of Hindu-Christian encounters have produced distinctive forms of Hindu thought which, while often rooted in the broad philosophical-cultural continuities of Vedic outlooks, grappled with, on the one hand, the colonial pressures of European modernity, and, on the other hand, the numerous critiques by Christian theologians and missionaries on the Hindu life-worlds. Thus, the spectrum of Hindu responses from Raja Rammohun Roy through Swami Vivekananda to S. Radhakrishnan demonstrates attempts to creatively engage with Christian representations of Hindu belief and practice, by accepting their prima facie validity at one level while negating their adequacy at another. For instance, these figures of neo-Hinduism accepted that such 'corruptions' as Hinduism's alleged idol-worship, anti-worldly ethic, castebased distinctions and the like were all too visible on the socio-cultural domain, while they formulated revamped Vedic or Vedantic visions within which these were to be either rejected as excrescences or given demythologised interpretations. In Swami Vivekananda, we find on some occasions a more strident rejection of certain aspects of western civilization as steeped in materialist 'excesses' which needed to be purged through the light of Vedantic wisdom. Through such hermeneutical processes of retrieval, often carried out within contexts structured by British colonialism, these figures were able to offer forms of Hinduism that were signifiers not of the Oriental depravity that the British administrators, scholars and missionaries had claimed to perceive on the Indian landscapes but of a spiritual depth that transcended national, cultural and ethnic boundaries.

The 'universality' of Hinduism thus begins to emerge from around the turn of the last century as the trope with which Hindu thought

Dr. Ankur Barua is Lecturer in Hindu Studies, Faculty of Divinity, University of Cambridge. His main research interests include (a) the classical Vedantic traditions and both their reformulations in contemporary India and their translations into western contexts, (b) comparative Hindu-Christian theology, and (c) the 'religion-science' debate in Indic contexts. His articles have been published in The Harvard Theological Review, Sophia, Journal of the Indian Council of Philosophical Research, International Journal of Hindu Studies, and The Heythrop Journal. His book, Between Benares and Bethlehem: Debating 'Conversion' in Hinduism and Christianity, is being published by Routledge under its 'Hindu Studies' series. His future projects include a study of the notion of 'divine friendship' in north Indian Vaishnavism, and a Vaishnavite commentary on selected parts of the Brahma-Sutra with St Augustine, Karl Barth, and Karl Rahner as purvapaksins.

Journal of Hindu-Christian Studies 27 (2014):77-94 
has been repeatedly characterised both on the Indian subcontinent and in its western receptions. The contrast between Hinduism as a spirituality that breathes the air of catholicity and the Abrahamic faiths such as Christianity, Islam and Judaism which are bigoted, dogmatic and intolerant has become a platitude in neoHindu representations of the latter. According to S. Radhakrishnan's vigorous accusation, 'The intolerance of narrow monotheism is written in letters of blood across the history of man from the time when first the tribes of Israel burst into the land of Canaan. The worshippers of the one Jealous God are egged on to aggressive wars against people of alien cults. They invoke Divine Sanction for the cruelties inflicted on the conquered. The spirit of old Israel is inherited by Christianity and Islam'. ${ }^{1}$ In contrast, Hinduism is marked out by its 'universal' vision that accepts different ideas of the ultimate and recognizes that human beings have attained different stages of spiritual perfection and seek the transcendent reality through diverse routes: 'By accepting the significance of the different intuitions of reality and the different scriptures of the peoples living in India, Hinduism has come to be a tapestry of the most variegated tissues and almost endless diversity of hues'. ${ }^{2}$ The contrast often recurs in contemporary views regarding what distinguishes Hindu 'spirituality' from the Abrahamic traditions, for instance, in the comment by Ram Swaroop that 'Hinduism is the only adequate religion of the Spirit. In contrast, Islam and Christianity are not religions; they are ideologies and, in their true essence, political creeds'. ${ }^{3}$ The 'Eastern' religions, rooted in a 'mystical' search by individuals for the truth in the interiority of their being, lead to visions of wholeness, unity and harmony, while 'revelatory religions' that follow the self-revelation of God to a favoured intermediary unleash violence, hatred and desolation on their competitors. ${ }^{4}$ Arun Shourie draws the contrast in even more strident terms, when he argues that every 'revelatory, millennialist religion', whether it is Christianity, Islam, Marxism-Leninism-Maoism, is grounded in the notion of one Truth, revealed to one Man, enshrined in one Text, and guarded over by one Agency. Further, such 'religions' generate violence towards their others through the claim that the promised Millennium shall dawn over humanity only if and when the institutionalised Agency ensures that all individuals do see the Light refracted through themselves as its focal point. ${ }^{5}$ In contrast to these religions rooted in specific, historical revelations, which breed hostility through the exclusionary logic of either/or, the 'pluralism' of Hindu thought, undergirded by the inclusionary logic of many/and, is offered as an outlook that can encompass religious diversity in a non-violent manner, by viewing the religious expressions of humanity as valid responses to the transcendent reality that circumscribes us all. Thus, while Millenarian faiths produce collective identities centred around specific foci, which lead to the demonization of the other, Hinduism is instead presented as the all-encompassing horizon that fosters the conversation of humanity, a horizon often characterised by the metaphors of many rivers merging into one ocean, many tones welded into one symphony, and many roads culminating into one summit.

The connection between religious pluralism and hospitality towards the religious alien, which is a recurrent theme throughout the multiple strands of neo-Hinduism, has been 
emphasised in recent decades also by various kinds of postmodernists and sometimes by Christian theologians themselves. For the former, all types of totalitarian thought cannot but lead to violent expressions against the others who are 'constructed' as evil, perverse or wicked, and who need to be reined in, even if through coercive mechanisms, to see the Truth. Since monotheism is one of the many versions of commitment to the Name, identified with a 'jealous God', it is not surprising, according to this line of argumentation, that those who refuse to accept such an 'exclusivist' foundation are hounded as dissenters, heretics and infidels. Monotheistic faiths provide a cosmic authorization to the processes of othering through which a community forges its own identity: 'Whether as singleness (this God against the others) or totality (this is all the God there is), monotheism abhors, reviles, rejects, and ejects whatever it defines as outside its compass'. ${ }^{6}$ The specifically Christian dimension of these postmodern anxieties relating to the suppression of alterity emerges when Christian theologians argue about the type and level of Christianity's complicity in the Holocaust and the medieval Crusades, and about a 'theology of the religions' that takes into account the sociological reality of religious diversity. While it would be rash to speak of a consensus among Christian theologians on the question of how the world religions can be accommodated within a Biblical horizon, their engagements with it have often been shaped by their responses to the 'pluralism' that appears in the work of theologians such as John Hick, Paul Knitter and Stanley J. Samartha. According to them, a 'pluralist' attitude to the world religions should go beyond a christocentric focus and speak of them as the multiple foci through which a deeper Reality, mystery, transcendence, engagement with liberation, and so on, is expressed with contextual culturespecific variations in them. That is, 'pluralism' as a new paradigm in a Christian theology of the religions would, in the view of its proponents, open up spaces where their adherents can meet in mutual conversations, engage in a joint search as they seek to translate to one another their distinctive notions of 'transcendence' and 'salvation', and forge solidarities in struggles against oppression and injustice.

Religious pluralism, in short, appears as a key theme in at least three central areas of discourse concerning 'religion': neo-Hindu representations of the Abrahamic faiths, which in turn have often been decisive in shaping perspectives towards the latter among New Age groups, postmodernism-inflected theorists who have pointed to the violent underside of Abrahamic monotheisms, and Christian theologians of a pluralist position regarding the world religions. An underlying theme that connects these distinct streams of thought is the concern that multiple forms of violence, exclusion and hostility have been ever-present features on the historical landscape of the Abrahamic faiths. ${ }^{7}$ The crucial question is whether this association is to be seen, to invoke the terms of formal logic, as correlation or as causation - that is, whether the numerous instances of religious persecution observed in Abrahamic socio-religious universes are to be regarded as empirically observed covariations or as structural concomitants of their inner logic of 'exclusivist' truth-claims. ${ }^{8}$ The former thesis would show that the relation between the Abrahamic faiths and their violent expressions is a contingent flaw, a flaw that 
itself can be accounted for through the theological apparatus of these faiths, for instance, original sin and its variants; the latter would demonstrate that these faiths necessarily generate violent, hostile and brutal attitudes to the religious other. To decide the matter in a comprehensive manner would demand several volumes, investigating the relations between religion and violence from philosophical, theological, historical, psychoanalytic and sociological perspectives. In lieu of such comprehensiveness, the present essay is offered as a minimal contribution to this complex of issues by exploring, from the specific context of Hindu-Christian interreligious encounters, a key question that would structure such an investigation: what are the distinctive bases on which to build Hindu and Christian forms of hospitality to the religious alien? We shall argue that both Hindu and Christian versions of 'pluralism' are rooted in distinct foci through which religious diversity is interpreted, analysed and reconfigured, and question the view that the mere presence of such foci in a religious worldview necessarily leads to violent exclusions of the others. Further, we shall note that the distinctiveness of Hindu 'pluralism', with respect to its Christian versions, is that it allows the possibility of post-mortem progress in ways that are not always affirmed by the latter, an affirmation that enables the former to develop somewhat more relaxed approaches to religious diversity. The overall point that we will emphasise is therefore that the differences between the Abrahamic faiths, on the one hand, and the Hindu religious traditions on the other regarding the world religions would be misrepresented if presented as a contrast between 'particularistic' outlooks that revolve around specific conceptual pivots and 'universalistic' ones that turn around none rather, both are rooted in philosophicaltheological matrices that can be activated to support distinctive stances of hospitality towards the religious other.

\section{The Logic of Hindu Pluralism}

The Hindu 'pluralist' approach to religious diversity has often been exalted for striking the notes of harmony, consilience and friendship among the world religions. The Hindu scriptures such as the Upanishads, and the streams of Hindu religiosity, possess powerful resources that can be drawn upon to foster attitudes of cordiality and openness towards the religions of the world. Themes such as the emphasis on a contemplative inner turn to the depths of the spirit, the tentative nature of human formulations of the nature of the divine, the vision of the empirical world as somehow pervaded by the transcendent as the inner self of all, the integration or even the union of the human with the ultimate reality, the choice of a favoured deity to be worshipped (isța-devatā) and so on can be found across the religious literature, and have been utilised to develop non-antagonistic and non-exclusionary views of religious diversity, especially by proponents of neo-Hinduism. However, the very fact that these doctrinal elements have been at the core of neo-Hindu approaches to religious diversity highlights the point that Hindu 'pluralism' is based not on some sort of doctrinal nihilism but on some specific points of doctrine. Sometimes these elements are not clearly highlighted in presentations of Hindu 'pluralism'; however, they provide it with the required conceptual underpinning that prevents it from lapsing into a boundless relativism of anything goes. For 
instance, V. Raghavan depicts the co-existence among religions fostered by Hindu spirituality in the following terms: 'According to one's stage of evolution and background, one can choose one's deity and continue the worship until, rising rung by rung, one reaches the highest where all forms dissolve into the one formless. Because of this free choice of approach, Hinduism has developed a philosophy of co-existence with other religions and has always been tolerant and hospitable to other faiths like Islam and Christianity'. ${ }^{9} \mathrm{~A}$ close reading of this statement would show that the Hindu 'pluralist' orientation is rooted in a dense network of metaphysical and anthropological views: first, that personal categories of divinities are penultimate pointers to the realisation of one's essential identity with the formless Absolute intimated by Advaita, second, that the true locus of personhood is the spiritual self and not the psychophysiological aggregate; third, that the attainment of spiritual perfection is a project that can be fulfilled across several life-times depending on one's stage of progress, and fourth, that religions such as Islam and Christianity which view the ultimate as personal are not completely erroneous but possess fragments of the Advaitic truth of nondual awareness as the true Self underlying all.

A more precise description of neo-Hindu 'pluralism' would therefore be 'hierarchical inclusivism', in which the numerous religious traditions of the world are ranked in a hierarchical manner with respect to the apex of Hindu wisdom, in many cases, neo-Advaita, that is, the modern reformulations of the Advaita of Śamkara offered by figures such as Swami Vivekananda (1863-1902) and S. Radhakrishnan (1888-1975). Swami
Vivekananda strikes this note when he urges us to gather nectar from many flowers in the manner of bees which are not restricted to only one; therefore, Swami Vivekananda expresses a wish for a 'twenty million more' sects which would provide individuals a wider field for choice in the religious domain. ${ }^{10} \mathrm{He}$ argues that the religions of the world 'are not contradictory; they are supplementary', in the sense that: 'Each religion, as it were, takes up one part of the great universal truth, and spends its whole force in embodying and typifying that part of the great truth'. ${ }^{11}$ A close reading of Swami Vivekananda shows, however, that the phrase the great universal truth' does not invoke a form of conceptual relativism according to which the truth is constructed by individuals in divergent ways depending on their cultural locations, but points to the Advaitic realisation of unitary awareness as the underlying depth of all phenomenal existence. Thus, reading the proclamation of Christ 'I and my Father are one' through a specifically Advaitin lens, Swami Vivekananda argued: 'To the masses who could not conceive of anything higher than a Personal God, he said, "Pray to your Father in heaven". To others who could grasp a higher idea, he said, "I am the vine, ye are the branches", but to his disciples to whom he revealed himself more fully, he proclaimed the highest truth, "I and my Father are One". ${ }^{12}$ As a disciple of Ramakrishna Paramahamsa (183686) who experimented with theistic, nontheistic, personal as well as impersonal forms of mysticism as alternative approaches to the supreme reality, Swami Vivekananda too sometimes speaks of the harmony that his master achieved between the teachings of the followers of Śamkara, on the one hand, and 
theists such as Rāmānuja on the other hand. ${ }^{13}$ However, the 'higher' standing of Advaitic wisdom with respect to the devotionalism of the masses is also emphasised in passages such as these: 'Devotion as taught by Narada, he used to preach to the masses, those who were incapable of any higher training. He used generally to teach dualism. As a rule, he never taught Advaitism. But he taught it to me. I had been a dualist before'. ${ }^{14}$

The hierarchical positioning of the religious traditions of the world with respect to the higher-order truth of Advaita appears more prominently in writings by figures from the Ramakrishna Mission founded by Swami Vivekananda. As Walter G. Neevel points out: 'It has been the characteristic view of the Ramakrishna Mission that theistic religion does find and must find its consummation and final satisfaction in the trance of nirvikalpa samādhi in which all personality, human or divine, vanishes. In this light, those Christian, Jewish, Muslim and Hindu traditions that are based upon the conception of a personal Deity are seen as being of positive but preparatory value'. ${ }^{15}$ For instance, Swami Abhedananda of the Ramakrishna Order argues that Advaita Vedanta is the best commentary on the teachings of Christ, so that to know more about Christ, Christians should go not to the church but to the fonts of Vedantic wisdom. ${ }^{16}$ The affirmation of a harmony of religions at the provisional level, because this level is ultimately grounded in the transpersonal Absolute indicated by Advaita, is also a characteristic feature of Radhakrishnan's view on religious diversity. On the one hand, Radhakrishnan emphasizes that the different religions, with their specific impulses and values, should learn from one another in amicable relationships because they are not incompatibles but complementaries, 'and so indispensable to each other for the realization of the common end'. ${ }^{17}$ Therefore, the Hindu who chants the Vedas, the Chinese who reflects on the Analects, and the European who worships Christ as the mediator can all access the Supreme through these specific contextual routes. On the other hand, however, when Radhakrishnan invokes the metaphor of the summit from which the spiritual landscape can be surveyed and all pathways seen to culminate there, he is clear that it is to be identified not with various types of personal devotion but the Advaitic realization of identity with the transpersonal Absolute. ${ }^{18}$ Consequently, the Abrahamic faiths do not have to be rejected as utterly erroneous because their limited, partial truths of personal theism can be corrected and elevated to the highest wisdom of Advaitic realisation. Therefore, he points out, regarding a Christian who approaches a Hindu teacher for spiritual guidance, that the latter 'would not ask his Christian pupil to discard his allegiance to Christ but would tell him that his idea of Christ was not adequate, and would lead him to a knowledge of the real Christ, the incorporate Supreme'. ${ }^{19}$ The numerous forms of devotion to a personal God, whether in the Abrahamic traditions or in the devotional strands of Hinduism itself, therefore, have fallen short of the fullness of Advaitic truth; nevertheless, even individuals in these traditions, who are now struggling with kärmic defects are capable of spiritual progress in this life-time as well as subsequent life-times. Therefore, Radhakrishnan's view that individuals choose forms of relating to the divine in distinct ways given their psychological temperaments, cultural frameworks and historical epochs 
should not be mistaken for the thesis that the 'divine' itself is somehow a product of these contingent determinants, for such relativisms at the empirical level are grounded in the transpersonal Absolute-the timeless non-dual Self which is independent of human beliefs and linguistic constructions.

The analysis of the structure of neo-Hindu 'pluralism' therefore shows it to be grounded in a specific theological anthropology underlying the empirical ego and its manifold experiences, there is an inner core that is deathless, non-created, and absolutely real, which is the unconditioned spirit completely untouched by the imperfections of the finite universe that is existentially dependent upon it. The timeless Spirit is the foundation of all expressions of human religiosity, including the Abrahamic faiths, and individuals in the latter can spiritually progress across several lifetimes till they attain the highest goal of realisation of their identity with it Therefore, while the text from the Rg Veda 'Truth is one, the wise call it by several names' (1.164.46) is often employed in discussions of Hinduism as fostering a universalistic harmony of the world religions, a closer analysis of these claims shows that terms such as the 'common end', 'final goal' or 'ultimate reality' are often given a specific Advaitin reading, so that theistic approaches to the transcendent as regarded as limitations of the ineffable Absolute. The theological apparatus of karma and rebirth which provides the support for this hierarchical inclusivism was, however, not invented ex nihilo by proponents of neoHinduism; rather, this was the hermeneutical strategy adopted even in classical and medieval Hinduism to locate the internal others on the philosophical-religious spectrum. The Kṛșna of the Bhagavad Gitā provides the paradigm for this mode when he tells Arjuna that $\mathrm{He}$ is the ultimate recipient of sacrifices to the lower gods; the formal structure of this argument is used by Vaiṣnavites to argue that the worshippers of Siva receive their blessings ultimately from Viṣnu, as well as by Śaivites to depict Vișnu as a worshipper of Siva. Figures in the tradition of south Indian Vaișnavism have even sometimes explained the multiplicity of deities on the religious pantheon by suggesting that these are in fact the productions of the highest Lord Viṣnu-Nārāyaṇa for those individuals who do not seek the supreme goal. Pillan, a 12th-century disciple of Rāmānuja, raises the question why the supreme Lord Viṣnu-Nārāyaṇa leads some individuals to take refuge with other gods, and answers in the following way: 'If all were liberated, then this earth, where people who do good or evil deeds can experience the fruits of their karma, would cease to function. To ensure the continuation of the world, the omnipotent supreme Lord himself graciously brought it about that you who have done evil deeds will, as a result of your demerit, resort to other gods and accordingly repeat births and deaths'. ${ }^{20}$ Medieval doxographers such as Mādhava (14 ${ }^{\text {th }}$ century CE) and Madhusūdana Sarasvatī (16 ${ }^{\text {th }}$ century CE) carried on this theme of hierarchical universalism to locate a wide range of philosophical views at different ranks in a hierarchical scheme, at whose pinnacle they placed Advaita Vedānta. For instance Mādhava placed a series of philosophical-theological systems in such a manner that the truth of the succeeding item on the list negated and corrected the deficiencies of the former. The hedonists (Cārvākas) are defeated by the Buddhists, who are overturned by the Jainas, 
who are refuted by the various devotional systems of Vaiṣnvism and Śaivism, till one arrives at the penultimate stage of Yoga, whose truth is most fully realised in Advaita Vedānta. ${ }^{21}$ While Advaita often appears at the summit of the religious expressions of humanity in neo-Hindu reconstructions of religious diversity, modern-day Vaișnavites too have employed the scheme of hierarchical inclusivism with respect to Advaitic nondualism and Abrahamic faiths such as Christianity. For a contemporary instance, we may turn to Swami Prabhupada, the founder of ISKCON, according to whom Jesus is not only an authentic representative of God, but is, in fact, the son of Kṛșna, so that Christians, even when they do not have explicit knowledge of Kṛṣna, are by spiritual nature eternal servants of Krș̣na. ${ }^{22}$

\section{Christian Theology and Religious Diversity}

The types of Hindu 'pluralism' that we have investigated, whether from neo-Advaitic perspectives or Vaișnavite traditions, therefore affirm the value of religious diversity because such diversity is reinterpreted, with the help of a specific metaphysics and theological anthropology, as containing possibilities of progress, across several life-times, towards the highest goal, whether this is the non-dual awareness of Advaita, the Lord Viṣnu-Nārāyaṇa and so on. While these types can be, as we have noted, by and large fall into the structure of a 'hierarchical inclusivism', the Christian engagements with religious diversity reveal a sharp disagreement among theologians regarding the status of the world religions in the providential economy. The differences can sometimes be traced back to the divergent notions that Christian theologians have regarding the relation between 'nature' and 'grace': those who hold that all of 'nature' is corrupted, and does not contain any God-ward orientation unless regenerated by 'grace' tend to view religious diversity as a sign of the fall, whereas those who argue that even 'nature' is always-already infused with 'grace' often place the various religions of the world in the divine providence. As a representative of the former view, Harold Netland writes that 'regardless of whatever goodness, beauty and truth we find in other religious traditions, we must not forget that the fact of religious diversity as we know it is in itself an effect of the Fall and sin. If it were not for sin, there would not be this radical pluralization of religious responses to the divine ... The Christian cannot, then, simply accept the plurality of religious ways as part of the diversity of God's creation, for even when considered in the most positive light possible, the fact of multiple religions represents a distortion of God's intention for his creation. ${ }^{23}$ One of the most well-known proponents of the latter view, namely, that human beings in the other religious traditions of the world too are somehow oriented towards the Christian God, appears in the Roman Catholic theologian Karl Rahner. Because human beings are included within the ambit of the divine salvific will, their spiritual life is continuously influenced by the grace of God, though this prevenient grace may remain anonymous until it is interpreted in response to Christian preaching. Therefore, when the message of faith reaches the individual she is made consciously aware of a gracious reality of which she did not have conceptual knowledge but within which she was already encompassed. ${ }^{24}$ The key question of course is whether the non-Christian religions per se can be regarded as channels for 
supernatural salvation, and on this question the documents of Vatican II such as Nostra Aetate do not offer clear pronouncments. On the one hand, Nostra Aetate declared that the truths (vera) in the non-Christian religions are 'a ray of that truth (Veritas) which enlightens all men' (NA 2), it also makes it clear that the Truth here refers to Christ himself "in whom men find the fullness of religious life, and in whom God has reconciled all things to Himself'. The silence has been construed by theologians in two divergent ways depending on their presuppositions concerning the relationship between 'nature' and 'grace': those who emphasise a close relationship between the two are usually of the opinion that the documents affirm the possibility that non-Christian religions could be salvific structures, while those who envisage a sharper distinction between the two reject the former opinion. ${ }^{25}$

In short, whether religious diversity is seen in these Christian traditions as a consequence of $\sin$ or as a signifier of the abundance of grace, it is viewed through the specific pivot of the redemptive work of Christ. The mainstream Christian traditions affirm that it is in, through and around Jesus Christ that God acted in the past and continues to act in the present, and it is through him that the right pattern of relationships between God, humanity and the world can be established. Proponents of 'pluralism' such as Hick object to the presence of such pivotal elements in Christian interpretations of religious diversity on the grounds that such reconstructions approach the religions from the particularistic axis of the Christ-event. However, as several scholars have pointed out, 'pluralism' itself is grounded in some highly specific epistemological and ontological presuppositions are in fact located within the European Enlightenment tradition, such as an ontological rupture between the transcendent and the world which denied that the former could act in and be involved with the continuing history of the latter, the notion of a tradition-constituted enquiry was replaced by a universal decontextualised rationality which would also be the ground of a (Kantian) universal ethics. In the attempt to give significance and maintain the authenticity of the diverse religious experiences of humanity, Christian 'pluralism' offers certain hypotheses which, in fact, revolves around the deities that are associated with modernity, such as agnostic or Unitarian. ${ }^{26}$ Consequently, the historical and cultural contingencies of the particular religions such as Christianity, Islam and theistic Hinduism are de-emphasised, and the possibility that there might exist genuine and deep-seated conflicts between the truth-claims of different traditions is downplayed or ignored.

\section{Pluralism and Hospitality to the Religious Alien}

Our discussion in previous sections has shown that both the Hindu traditions - neoAdvaita, Vaișnavism and so on - and the Christian traditions - the many varieties of Protestantism and Roman Catholicism - all employ specific criteria to reconfigure religious diversity. Indeed, even what is referred to as Hindu 'pluralism' in neo-Hinduism and Christian 'pluralism' of theologians such as Hick turn out to be rooted in particularistic metaphysical and anthropological views. In other words, these diverse strategies of engagement with religious diversity are rooted in religious truth-claims which are usually absolute, and such 'tendencies to absoluteness, although they have certainly been typical of 
Christian doctrines, are not typical only of them; they are characteristic also of many of the most interesting claims made by the religious virtuosi of non-Christian traditions'. ${ }^{27}$ For instances of such claims, we may turn to Samkara who argued that individuals who are desirous of the highest end should turn away from Buddhism, and his arch-rival Rāmānuja argued that the teachings of Advaita had been 'devised by men who are destitute of those particular qualities which cause individuals to be chosen by the Supreme Person revealed in the Upanishads; whose intellects are darkened by the impression of beginningless evil; and who thus have no insight into the nature of words and sentences, into the real purport conveyed by them... ${ }^{28}$ By grounding himself on the criterion of Vedic revelation, Kumārila Bhatța $(650-700 \mathrm{CE})$ denied the status of orthodoxy not only to the Buddhists, but also to the Sāmkhya and Yoga systems, and the theistic Śaiva Pāśupata. ${ }^{29}$ The numerous Purāṇas, some of which are written from distinctively Vaiṣnavite and Śaivite perspectives, carry on with sharp invectives against their doctrinal rivals. For instance, the Viṣnupurāna includes exhortations to avoid any form of contact with the Buddhist heretics who have transgressed the norms of Vedic life, and the Padma Purāna declares that the teachings of the Vaiśeșika, Nyāya, Sāmkhya, and Śamkara's Advaita Vedānta lead to hellish suffering. ${ }^{30}$ From a Saivite standpoint, the late eleventh century theologian Somaśambhu turns the tables on the Vaiṣnavites: the worshippers of Viṣnu will be reborn in hell unless they undergo a ritual transformation to Śaivism. ${ }^{31}$

The key question that emerges from this comparative analysis of the structure of Hindu 'pluralism' and Christian responses to religious diversity therefore is not whether but why the world religions are to be accorded at least provisional acceptance. We have already discussed the neo-Hindu answer - the religious traditions of the world are positively valued not as an end in themselves but because they are channels within which individuals can progress across life-times to the supreme end, whether Advaita, the Lord Viṣnu-Nārāyaṇa and so on. More specifically, neo-Advaitins could argue that individuals who follow the way of personal theism (whether in the Abrahamic faiths or the streams of devotional Hinduism) are, in fact, burdened with kārmic defects which obscures their mental and spiritual horizons, and when these barriers are removed, either in this lifetime or in subsequent ones, they too would be set on the path towards the unitary awareness of the transpersonal Absolute. Further, given the absence of centralized ecclesiastical structures to enforce specific creedal formulations over the 'faithful' the conglomerate of the socio-religious Hindu traditions have historically accepted a wide diversity of metaphysical and theological views, and the persecution of dissent associated with the Christian centuries has been, by and large, absent in them. However, there is no strict logical connection between the belief that one has grasped, however fallibly, some elements of the truth revealed through a specific focal point and the belief that one must persecute those who refuse to accept it. While it is historically true that the Christian tradition has often been associated with triumphalist attitudes over other religions, culminating in numerous brutalities on people characterised as pagans and heretics, the view that nonChristian individuals are mistaken in some ways does not logically entail the persecution 
of the latter. It is possible to combine the belief in truth (of Christian doctrine or Advaita metaphysics) with a belief in the freedom of conscience of the individual, which as a corollary implies the freedom to err. For instance, the international missionary council at Tambaram declared that God wishes that human beings, made in the imago Dei, will seek a fellowship both with their creator and with their brothers and sisters on earth, but in the 'mystery of freedom' has allowed human beings to seek other paths when they reject the way that leads to God. ${ }^{32}$ More recently, Vatican II affirms not only that all human beings 'share a common destiny, namely [the Triune] God. ${ }^{33}$ (Nostra Aetate 1) but also that nobody should be coerced to accept the Christian faith against their own will (Dignitatis Humanae 10).

We are in a better position to evaluate the following presentation of Hindu 'pluralism' by N.S. Rajaram: 'If there is one belief above all others that defines Hinduism it is pluralism: there is no one chosen path and no one chosen people ... All paths of spiritual exploration are equally valid, and there is no such thing as heresy'. ${ }^{34}$ As we have noted in our discussion of classical and modern Hinduism, it is somewhat misleading to present Hindu 'pluralism' as the view that the different religious paths are 'equally valid', for what is affirmed is their provisional validity, provisional, that is, to the attainment of the highest end. At the same time, Rajaram's contrast is accurate to the extent that the Hindu worlds have been relatively free from the organised persecution of dissent that has been a feature of the Abrahamic faiths with their notions of a chosen fulcrum for salvationhistory. However, the reason why Hindus sometimes display 'multiple allegiance' to different deities and forms of devotion is not because the truth-claims of all religious systems are taken to be valid, but because of specific understandings of human personhood, the nature of ultimate reality and the possibility of spiritual progress: the doctrine of karma and rebirth allows a somewhat relaxed orientation to religious diversity, by keeping open options that individuals could exercise over time to attain the supreme goal of fulfilment. ${ }^{35}$

\section{The Nature of Post-Mortem Progress}

If the conceptual presuppositions of religious Hinduism enable a vision of spiritual progress that is not limited to the span of a single life-time, the crucial question is whether such a vision can be incorporated into Christian theological understandings of the cosmic redemption. While the doctrine of reincarnation has usually been regarded as antithetical to certain elements of Christian orthodoxy, contemporary theologians have sometimes offered a view of post-mortem progress that resonates in certain ways with the Vedantic outlook on perfectionism beyond the present life. The theological challenge is to affirm that God who was, and continues to be, active in Jesus Christ has offered salvation to all and not just to a segment of humanity ('theological regionalism') nor only to those who lived within a particular strand of history ('theological epochism'). ${ }^{36}$ An age-old question for Christian theologians therefore has been the destiny of those who died in ignorance of Christ, for given the conviction that reconciliation to God is possible only through Christ it would seem to be 'unfair' on the part of God to condemn such individuals.

At least three moves are available to Christian theologians at this juncture. First, by 
appealing to a doctrine of divine ineffability, one could argue that the standards of human 'fairness' should not, in fact, be applied to God. ${ }^{37}$ In a famous debate with Julian of Eclanum over whether God judges human beings according to their merits, St Augustine argued that in response to questions such as why God chose Jacob over Esau (Romans 9:13) even before their births when there could have been no moral differences between them, one must appeal to the hiddenness of God's justice (De Praedestinatione Sanctorum 6.11). In fact, St Augustine says that he calls God 'just' simply because he cannot find a better word, and that our human conceptions of justice cannot be applied to God who is beyond justice. ${ }^{38}$ An Augustinian response, therefore, to the question of the status of those who died unbaptized because they had not heard of Christ would be to appeal to divine mystery: one cannot 'rationalize' the divine dealings with fallen creatures by claiming that God must dispense justice, like a human judge, by dealing with each individual separately according to her deserts (De Civitate Dei 14.26). A second move, related to the first, argues that the world has been providentially created with an optimal balance between the saved and the lost in such a way that those who fail to hear the Gospel would not have freely responded even if they had, in fact, heard it. William Craig develops this position by appealing to Luis Molina's thesis of 'middle knowledge' - the knowledge that God has of how people would freely respond in all possible sets of circumstances. Therefore, Craig claims that it is not inconsistent, given middle knowledge, to claim that God is all-loving and all-powerful and yet that some people freely choose not to turn to God. ${ }^{39}$ What these two moves have in common is the view that death is the 'cut-off' point beyond which there is no possibility of a moral transformation. Further, one cannot accuse God of 'unfairness' either because such accusations are based on an improper extension of human vocabulary to God who is shrouded in mystery or because the world is providentially structured in such a manner as not to violate an individual's free choice not to choose God. Third, however, some theologians have grappled with the question of 'theological regionalism' and 'theological epochism' by postulating the possibility of post-mortem purification. For instance, S.T. Davis invokes Biblical texts which speak of Christ's descent into Hades to suggest that individuals are given a chance to hear the gospel (for the first time) after their deaths, which could be followed by a positive response to Christ on their part. ${ }^{40}$ The Roman Catholic theologian Joseph DiNoia employs a version of this argument to speak of a purgatorial purification undergone by members of other religious traditions: though Christians wish to attribute the truth and goodness they encounter in non-Christian religions to the inspiration of the Spirit, in order to affirm the distinctiveness of the religious aims in these communities, a Christian evaluation of "such qualities could be framed in terms of an "eschatological" rather than a present salvific value. The specific ways in which the presently observable and assessable conduct and dispositions of nonChristians will conduce to their future salvation are now hidden from view and known only to God'. ${ }^{41}$ In other words, in order to affirm the particularistic claims of both Christianity (that communion with the Triune God is the 'true' aim of all human beings) and other religions, Christians will value these religions not as 
channels of (Christian) salvation now but in terms of their prospective role in God's plan for humanity, a role which cannot (as yet) be clearly specified. In this connection, DiNoia appeals to the Catholic doctrine of purgatory which teaches that there is (often) an interval between a Christian's death when she undergoes a process of purification so that she may enter into a full communion with the blessed Trinity. He writes that Christians may with 'a wide measure of confidence' extend this doctrine to non-Christians so they too may go through a similar post-mortem interval, during which they will probably realize the various degrees of dis/continuity with their earthly aims and dispositions, and be granted the divine offer of the beatific vision. ${ }^{42}$

The Indian Christian theologian Origen Vasantha Jathanna goes beyond these formulations and speaks more explicitly of a Christian understanding of rebirth, which he argues follows from the understanding of the Christian revelation. As he grapples with the question of the destiny of human beings who (have) died in an ante Jesum Christum natum situation, either because they were born, in a chronological sense, before the Christ-event or because they did not receive an opportunity to come into a direct contact with it, Jathanna argues that any proposed solution must seek to hold together two vital truths. Firstly, the decisiveness of the Christ-event for all humanity, and indeed for the entire universe, and, secondly, the universal salvific outreach of the God of love who wills that all develop a right relationship and enter into a fellowship with God through the knowledge of the Christevent. ${ }^{43}$ According to his solution, human beings who have died without encountering the christ-event (chronologically both before and after it) may be reborn into a situation where they shall have the opportunity of knowing about Christ and entering into a relationship with him. Given the corporate dimensions of human existence, it may be difficult for individuals in some socio-cultural contexts to adequately know about and respond to the Christ-event, and in such cases, the gracious God who seeks their personal growth may bring it about that they born into the world again. In arguing for a Christian appropriation of certain aspects of the doctrine of rebirth, Jathanna wishes to distance this suggestion from certain interpretations which hold that human beings are sent into the world as a punishment for a pre-mundane fall, or that they are under the sway of a rigidly juridical system of moral causation. Rather, he argues that his perspective on rebirth is guided by the Christian hope of the salvation of all which is derived from the revealed character of God: 'We can, therefore, have a genuinely Christian concept of Rebirth, which springs from, and is demanded by, the very attempt of understanding the Christian revelation. ${ }^{, 4}$

While our concern here is not to analyze in detail the relative merits of either the purgatorial or the rebirth 'solution', we note three major implications of these formulations which seek to respond to the question of the theological status of individuals who die unbaptized. First, while Hindu theology rejects the basic presupposition of the first two moves noted earlier and argues that human existence is a project that can be fulfilled across several life times, its devotional strands too have sometimes struggled with the 'Augustinian' question of whether the divine reality is under any 'necessity' to graciously intervene into a corruptible world. ${ }^{45}$ In a famous split in the Śrī- 
Vaișnava tradition after Rāmānuja, the 'northern school' argued that the Lord's gracious (prasāda) approach to the devotees was not unconditional but was responsive to their moral worthiness, whereas the 'southern school' claimed that the Lord's graciousness was unfathomable and freely given with no consideration of prior actions. ${ }^{46}$ Second, an adequate defence, or appropriation, of the doctrine of karma and rebirth would have to engage with philosophical-anthropological questions relating to personal identity, the mind-body problem, the status of moral causation, and so on. More specifically, from a Christian theological perspective, a vital question would be the relation between God and the 'law' of karma, a relation that, as we noted above, some of the Vaișnavite traditions too have struggled to explicate. ${ }^{47}$ Third, a Christian adaptation of the doctrine of rebirth would raise important questions for the understanding of mission, conversion, interreligious dialogue, and so on. As we have noted, the hierarchical inclusivism through which Hindu thought has been able to 'accommodate' the intra-religious other is structured, in part, by the doctrine of karma and rebirth, which holds open the possibility that all human beings, at some point in the future, may attain liberation. Thus an American tourist who wished to become a Hindu was asked by Sri Chandrashekhara Bharati Swami of the Sringeri monastery whether he had properly lived his Christian faith: 'It is no freak that you were born a Christian. God ordained it that way because, by the samskära acquired through your actions (karma) in previous births, your soul has taken a pattern which will find its richest fulfilment in the Christian way of life. Therefore your salvation lies there and not in some other religion' ${ }^{48}$ Christian theology in contrast has been historically marked by a sharp polarisation between soteriological 'universalists' and 'restrictivists': the former argue that all human beings will freely respond to salvation which is offered to all, either now or in the hereafter, and the latter argue that only a specific class of human beings have been predestined for the offer of salvation. In response to this divide, Jathanna argues that while salvation is offered to all, the 'attainment' of the highest good is not automatically guaranteed by the hypothesis of Christian rebirth: "While it is true that Rebirth can be related to universalism, the two do not necessarily belong together. Even if there should be numerous opportunities, a person can use them either to come closer to God or to go further away ... ${ }^{49}$ In short, the connection between rebirth and universalism is not necessary but contingent which seems to imply, in turn, that for Jathanna the preaching of the Gospel and the conversion of individuals to Christian discipleship remain fundamental aspects of Christianity's encounter with the world of religious diversity.

\section{Conclusion}

In short then, the question of whether or not the Hindu and the Christian religious world-views are based on normative criteria is a red herring; as we have noted, the structural depths of Hindu 'pluralism' reveal patterns similar to Christianity of reinterpreting religious diversity from distinctive metaphysical-theological lenses. The more fundamental question is whether the relative absence of religious persecution in the Indian subcontinent is to be explained in terms of the specifically Hindu set of theological- 
philosophical criteria or a complex of sociological, political and economic factors. As we indicated in the introduction, an adequate engagement with questions of this nature would require interdisciplinary collaboration across various academic fields; however, the answer would arguably point to a subtle intertwining of both the above type of influences. The intellectual development of the Hindu traditions has been shaped by an internal tension between, on the one hand, the ideals of the householder, who is often involved, for instance, as king or soldier, in violence of various sorts, and, on the other, the values embodied by the ascetic who abjures all kinds of violence. The classical literature consisting of texts such as the Upanișads, the Manusmṛti, the Bhagavad-Gìtā and the theological elaborations of systematisers such as Śamkara and Rāmānuja has variously emphasized one of these two over the other, or tried to synthesize them, so that Jeffery D. Long concludes: 'To generalize, mainstream Hindu thought is ambivalent toward violence'. ${ }^{50} \mathrm{In}$ conclusion, then, Hindu 'pluralism' should not be romanticized to paint Hindu cultures as pervaded by an undiluted nonviolence. ${ }^{51}$ However, its resources, underpinned both by the philosophical-theological complex of karma and rebirth and by the lack of rigid institutionalizations, can be drawn upon in exploring hospitable ways of responding to the religious alien in a world characterized by religious diversity. The somewhat relaxed attitude to liberation made possible by the kārmic order often appears in various levels of popular religiosity; for instance, notwithstanding the intense sectarian rivalry between Vaișnavites and Śaivites, the famous temple of Lingaraj-Mahaprabhu in
Bhubaneswar attracts pilgrims from both groups. ${ }^{52}$ Therefore, Vaiṣnavites have often 'accommodated' Śaivites into a wider Hindu theological fabric, and vice versa, not in the sense that they believe that their opponents are doctrinally correct about the nature of reality and of the human response to it, but in that that their opponents can attain rebirth subsequently in their own doxastic community, and thus, properly qualified, the opponents can finally move towards the goal of liberation.

\section{Notes}

${ }^{1}$ S. Radhakrishnan, The Hindu View of Life (London: Unwin Paperbacks, 1927), p. 40. http://dx.doi.org/2027/uc1.b3272677

${ }^{2}$ S. Radhakrishnan, The Hindu View of Life, p. 17.

3 Ram Swarup, On Hinduism: Reviews and Reflections (New Delhi: Voice of India, 2000), p. 50.

${ }^{4}$ Pope John Paul II on Eastern Religions and Yoga: A Hindu-Buddhist rejoinder (New Delhi: Voice of India, 1995), p. 27. http://dx.doi.org/2027/mdp.39015038034198

${ }^{5}$ Arun Shourie, Missionaries in India: Continuities, Changes, Dilemmas (Delhi: ASA, 1994), pp. 12-13.

${ }^{6}$ Regina M. Schwartz, The Curse of Cain: The Violent Legacy of Monotheism (Chicago: The University of Chicago Press, 1997), p. 63.

${ }^{7}$ Jonathan Ebel,'Christianity and Violence' in Andrew R. Murphy ed. The Blackwell Companion to Religion and Violence (Blackwell: Oxford, 2011), pp. 149-62. http://dx.doi.org/ 10.1111/b.9781405191319.2011.x

${ }^{8}$ Miroslav Volf, Christianity and Violence. The Boardman Lectureship in Christian Ethics. March 6, 2002. 
${ }^{9}$ Quoted in Milton Singer, When a Great Tradition Modernizes (London: Pall Mall Press, 1972), p.83. http://dx.doi.org/2027/uc1.32106014652967

${ }^{10}$ Swami Vivekananda, The Complete Works of Swami Vivekananda, vol. 1 (Calcutta: Advaita Ashrama, 1985), p.325. http://dx.doi.org/2027/mdp.39076000876313

${ }^{11}$ Swami Vivekananda, The Complete Works of Swami Vivekananda, vol. 1 (Calcutta: Advaita Ashrama, 1985), p.367. http://dx.doi.org/2027/mdp.39076000876313

${ }^{12}$ Swami Vivekananda, The Complete Works of Swami Vivekananda vol. 2 (Calcutta: Advaita Ashrama, 1985), p. 143. http://dx.doi.org/2027/mdp.39076000876321

${ }^{13}$ Swami Vivekananda, The Complete Works of Swami Vivekananda vol. 7 (Calcutta: Advaita Ashrama, 1985), p. 411. http://dx.doi.org/2027/mdp.39076000876370 ${ }^{14}$ Swami Vivekananda, The Complete Works of Swami Vivekananda vol. 7 (Calcutta: Advaita Ashrama, 1985), p. 414. http://dx.doi.org/2027/mdp.39076000876370

${ }^{15}$ Walter G. Neevel, 'The Tranformation of Sri Ramakrishna', in Bardwell L. Smith, Hinduism: new essays in the history of religions (Leiden: E.J. Brill, 1976), pp. 53-97, here p.96. http://dx.doi.org/2027/mdp.39015027589103

${ }^{16}$ Swami Abhedananda, Complete Works (Madras: Sri Ramakrishna Math, 1924), p. 376.

${ }^{17}$ S. Radhakrishnan, The Hindu View of Life (London: Unwin Paperbacks, 1927), p. 43. http://dx.doi.org/2027/uc1.b3272677

${ }^{18} \mathrm{~S}$. Radhakrishnan, Indian Religions (reprint edn, New Delhi: Orient, 1979), p. 98.

${ }^{19} \mathrm{~S}$. Radhakrishnan The Hindu View of Life (London, 1927), p. 34. http://dx.doi.org/ http://hdl.handle.net/2027/uc1.b3272677
${ }^{20}$ John Carman and Vasudha Narayanan, The Tamil Veda: Pillan's interpretation of the Tiruvāymoli (Chicago: University of Chicago, 1989), p. 208. http://dx.doi.org/2027/uc1.b3901860

${ }^{21}$ Andrew J. Nicholson, Unifying Hinduism: Philosophy and Identity in Indian Intellectual History (New Delhi: Permanent Black, 2011), pp. 164-5.

${ }^{22}$ Steven J. Gelberg, 'Krishna and Christ: ISKCON's Encounter with Christianity in America', in Harold Coward (ed.), HinduChristian Dialogue: Perspectives and Encounters (New Delhi: Motilal Banarsidass, 1993), pp. 138161, here pp. 152. http://dx.doi.org/2027/mdp.39015017740153 23 Harold Netland, Encountering Religious Pluralism (Leicester: Apollos, 2001), pp. 345-46.

${ }^{24}$ Karl Rahner, 'Nature and Grace', in Karl Rahner, Theological Investigations Volume IV / translated by Kevin Smyth (London: Darton, Longman and Todd, 1966), pp.165-88, here p. 181.

${ }^{25}$ Gavin D'Costa, The Meeting of Religions and the Trinity (Edinburgh: T \& T Clark, 2000), p. 102. http://dx.doi.org/2027/mdp.39015050130635 ${ }^{26}$ Gavin D'Costa, The Meeting of Religions and the Trinity (Edinburgh: T\&TClark, 2000), p. 20. http://dx.doi.org/2027/mdp.39015050130635 ${ }^{27}$ Paul J. Griffiths, An Apology for Apologetics (New York: Orbis Books, 1991), pp. 2-3.

${ }^{28}$ George Thibaut, The Vedanta-Sutras of Ramanuja (Oxford: Clarendon Press, 1904), p. 39. ${ }^{29}$ Francis X. Clooney, 'Hindu Views of Religious Others: Implications for Christian Theology', Theological Studies 64 (2003): 306-33, here p. 311. http://dx.doi.org/10.1177/004056390306400204

${ }^{30}$ Vishnu Purana, translated by H.H. Wilson (Calcutta: Punthi Pustak, 1961), p. 271-3. 
31 Andrew J. Nicholson, Unifying Hinduism: Philosophy and Identity in Indian Intellectual History (New Delhi: Permanent Black, 2011), p.3. 32 International Missionary Council Meeting At Tambaram, (London: Humphrey Milford, 1939), vol.1, p. 188.

${ }^{33}$ Austin Flannery, O.P. ed., Vatican Council II: The Conciliar and Post Conciliar Documents (Dublin: Dominican Publications, 1975), p. 738.

${ }^{34}$ N.S. Rajaram, A Hindu View of the World: Essays in the Intellectual Kshatriya Tradition (New Delhi: Voice of India, 1998), pp. 10-11. http://dx.doi.org/2027/mdp.39015041388557

${ }^{35}$ Gavin D'Costa, The Meeting of Religions and the Trinity (Edinburgh: T\&TClark, 2000), p. 65. http://dx.doi.org/2027/mdp.39015050130635

${ }^{36}$ Origen Vasantha Jathanna, The Decisiveness of the Christ-Event and the Universality of Christianity in a World of Religious Plurality (Berne: Peter Lang, 1981), pp. 36-40.

${ }^{37}$ John Rist, Augustine: Ancient Thought Baptized (Cambridge: Cambridge University Press, 1984), p.275.

${ }^{38}$ Sermo 341, 9 (419 CE): Justum quidem Deum dicis: sed intellige aliquid ultra justitiam quam soles et de homine cogitare ('You call God just; but you must understand something other than the justice you would attribute to a human being'.) ${ }^{39}$ William Lane Craig, “'No Other Name': A Middle Knowledge Perspective on the Exclusivisity of Salvation though Christ," Faith and Philosophy 6 (1989), pp. 172-88. http://dx.doi.org/10.5840/faithphil19896212 ${ }^{40}$ S.T. Davis, 'Universalism, Hell, and the Fate of the Ignorant' in Modern Theology 6 (1990), pp. 173-86. http://dx.doi.org/10.1111/j.14680025.1990.tb00214.x

${ }^{41}$ J.A. DiNoia, The Diversity of Religions: A Christian Perspective (Washington, D.C.: The Catholic
University of America Press, 1992), p. 75. http://dx.doi.org/2027/mdp.39015029187104 ${ }^{42}$ J.A. DiNoia, The Diversity of Religions: A Christian Perspective (Washington, D.C.: The Catholic University of America Press, 1992), pp. 105-7. http://dx.doi.org/2027/mdp.39015029187104

${ }^{43}$ Origen Vasantha Jathanna, The Decisiveness of the Christ-Event and the Universality of Christianity in a World of Religious Plurality (Berne: Peter Lang, 1981), p. 436.

${ }^{44}$ Origen Vasantha Jathanna, The Decisiveness of the Christ-Event and the Universality of Christianity in a World of Religious Plurality (Berne: Peter Lang, 1981), p. 479.

${ }^{45}$ Patricia Y. Mumme, 'Grace and Karma in Nammālvār's Salvation.' Journal of the American Oriental Society 107 (1987), pp. 257-66. http://dx.doi.org/10.2307/602834

${ }^{46}$ Srilata Raman, Self-Surrender (Prapatti) to God in Śrī-Vaiṣnavism: Tamil Cats and Sanskrit Monkeys (New York: Routledge, 2006).

${ }^{47}$ Bruce R. Reichenbach, 'Karma, Causation and Divine Intervention.' Philosophy East and West 39 (1989), pp. 135-49. http://dx.doi.org/10.2307 /1399374

${ }^{48}$ A. Sharma, Hinduism as a Missionary Religion (New York: SUNY Press, 2011), p. 126.

${ }^{49}$ Origen Vasantha Jathanna The Decisiveness of the Christ-Event and the Universality of Christianity in a World of Religious Plurality (Berne : Peter Lang, 1981), p. 477.

${ }^{50}$ Jeffery D. Long, 'Religion and Violence in Hindu Traditions', in Andrew R. Murphy ed. The Blackwell Companion to Religion and Violence (Blackwell: Oxford, 2011), pp. 196-210, here p. 196. http://dx.doi.org/10.1111/b.97814051913 19.2011.x

51 Martha Nussbaum, The Clash Within: Democracy, Religious Violence, and India's Future 
94 Ankur Barua

(Cambridge, MA: Harvard University Press, 2007). http://dx.doi.org/2027/mdp.3901506936

9125

${ }^{52}$ Julius Lipner, Hindus: Their religious beliefs and practices (London: Routledge, 1994), p. 238. 